\title{
Trening etter hjertetransplantasjon - gamle prinsipper for fall
}

\author{
Siden den første hjertetransplantasjonen i Norge i 1983 har tradisjonen vært at de hjertetransplanterte rådes \\ til å trene relativt forsiktig. Fordi det nytransplanterte hjertet mangler nerveforsyning og derfor har redusert \\ kronotrop respons, har intervalltrening vært et ikke-tema. Dette kan nå revurderes.
}

Nytransplanterte hjerter mangler nerveforsyning, og pasientene har derfor høyere hvilepuls, langsommere stigning av pulsen under belastning, lavere maksimal puls og langsommere normalisering etter endt belastning. Man har trodd at dette er en av hovedårsakene til den reduserte fysiske kapasiteten hos pasientgruppen, der de fleste studier viser et maksimalt oksygenopptak på 50-70\% av hva som er forventet hos friske (1). Redusert oksygenopptak er sterkt assosiert med en dårligere prognose hos denne pasientgruppen og er derfor en markør som er viet stor oppmerksomhet.

Årsaken til det reduserte oksygenopptaket kan imidlertid ha sammenheng med en rekke andre faktorer og skyldes sannsynligvis en kombinasjon av både sentrale (hjertet) og perifere (muskler og vev) begrensninger $(1,2)$. Intervalltrening med høy intensitet har vist seg å gi overlegne resultater sammenliknet med mer moderat trening hos pasienter med generell hjertesykdom (3), men hjertetransplanterte har vært skjermet for denne type trening som innebærer relativt raske skiftninger i hjertefrekvens. På grunn av manglende nerveforsyning og redusert hjertefrekvensrespons har man antatt at de hjertetransplanterte har liten toleranse for intervalltrening og at treningsformen som sådan ville være uegnet.

\section{Lovende resultater}

Siden 1999 er det publisert et lite knippe randomiserte studier av trening hos hjertetransplanterte pasienter (4-8) som alle viser en statistisk signifikant bedring i oksygenopptak blant dem som trener, men fortsatt langt fra forventet nivå hos friske (60-70 \% av forventet). Disse studiene har til felles at treningsintervensjonen har vært kondisjonstrening med moderat intensitet, det vil si $60-70 \%$ av maksimalt oksygenopptak.

De siste årene har det vært forsket mye på ulike treningsprinsipper, og høyintensiv intervalltrening har vist seg å være en svært effektiv treningsmetode hos friske, pasienter med metabolsk syndrom og pasienter med kransåresykdom og hjertesvikt $(3,9)$, idet maksimalt surstoffopptak bedres vesentlig i forhold til ved moderat trening. Siden 2009 er det publisert tre studier av høyintensiv intervalltrening hos hjertetransplanterte, der alle viste overlegne resultater sammenliknet med kontrollgrupper og hva som tidligere er vist ved annen type trening (10-12). Ingen av studiene har rapportert om uønskede hendelser i forbindelse med den intensive treningen.

En av disse studiene gjennomførte vi ved Rikshospitalet (12). Vi inkluderte 52 hjertetransplanterte pasienter fra hele landet i forbindelse med ordinær årskontroll. Deltakerne ble randomisert til intervalltrening eller kontrollgruppe. Kontrollgruppen forpliktet seg ikke til noen spesifikk treningsintervensjon, men skulle fortsette «som vanlig». Intervallgruppen forpliktet seg til trening sammen med fysioterapeut etter et fast program $(3 \times 8$ uker $)$ som var fordelt

\section{«Intervalltrening ser ut til å være både en trygg og effektivtreningsform for stabile hjertetrans- planterte pasienter
litt ut i forløpet»}

over ett år fra oppstart. Deltakerne i begge grupper var relativt spreke hjertetransplanterte (oksygenopptak på ca. $80 \%$ av forventet hos friske) med et velfungerende transplantat og god livskvalitet. Intervalltreningen besto av økter med ti minutters oppvarming etterfulgt av fire fire minutters intervalldrag med en gjennomsnittlig gjennomført intensitet på 91,5\% av maksimalpuls. I løpet av året gjennomførte deltakerne gjennomsnittlig 69 intervalløkter hver, pluss en del egentrening.

Etter endt treningsintervensjon kunne vi dokumentere signifikante forbedringer $\mathrm{i}$ intervallgruppen sammenliknet med kontrollgruppen $(12,13)$ : Bedre oksygenopptak/bedre kondisjon, økt utholdende muskelstyrke, bedre skåring på livskvalitet og redusert progresjon av vaskulopati (en spesiell form for arteriosklerose i kransarteriene hos hjertetransplanterte pasienter).

\section{Behov for flere studier}

Tradisjonelt sett har hjertetransplanterte pasienter blitt underlagt en del treningsres- triksjoner, deriblant skjerming for intervalltrening. Det finnes etter hvert mye dokumentasjon på at en viss reinnervasjon inntreffer og at nedsatt kronotrop respons ikke nødvendigvis er en begrensende faktor for redusert arbeidskapasitet på lengre sikt (14). Når det nå også er økende kunnskap om at intervalltrening ser ut til å være både en trygg og effektiv treningsform for stabile hjertetransplanterte pasienter litt ut i forløpet, er det på tide at det gjøres kjent og tilbys disse pasientene i større grad. Slik trening kan medføre redusert sykelighet og dødelighet i pasientgruppen, men det behøves nye, større studier over lengre perioder for å gi sikrere svar.

Resultatene er svært lovende, men det er likevel viktig å understreke at de hjertetransplanterte pasientene ser ut til å respondere noe forskjellig på intervalltrening sammenliknet med ikke-transplanterte pasienter, hovedsakelig med større treningseffekter perifert enn sentralt (15). Det er behov for flere og større studier der man undersøker disse mekanismene, ser på når i forløpet det er gunstig å introdusere intervalltrening og vurderer langtidseffekt av trening. På Rikshospitalet er vi nå i gang med en skandinavisk multisenterstudie der vi sammenlikner effekt av intervalltrening med moderat trening blant helt nytransplanterte pasienter. Inntil resultater fra denne studien foreligger, kan vi kun anbefale intervallbasert trening for friske, stabile hjertetransplanterte $>1$ år etter hjertetransplantasjon.

\section{Kari Nytrøen \\ kari.nytroen@medisin.uio.no Lars Gullestad}

Kari Nytrøen (f. 1971) er fysioterapeut og ph.d. Denne kommentarartikkelen er basert på hennes ph.d.-avhandling som i all hovedsak dreier seg om trening etter hjertetransplantasjon. Hun er postdoktor ved Kardiologisk avdeling, Oslo universitetssykehus, Rikshospitalet og spesialrådgiver i Avdeling for Kunnskapsstøtte, Sykehuset Innlandet.

Forfatter har fylt ut ICMJE-skjemaet og oppgir ingen interessekonflikter. 
Lars Gullestad (f. 1951) er spesialist i hjertesykdommer ved Kardiologisk avdeling, Oslo universitetssykehus, Rikshospitalet og professor ved Medisinsk fakultet, Universitetet i Oslo. Forfatter har fylt ut ICMJE-skjemaet og oppgir ingen interessekonflikter.

\section{Litteratur}

1. Hsieh PL, Wu YT, Chao WJ. Effects of exercise training in heart transplant recipients: a metaanalysis. Cardiology 2011; 120: 27-35.

2. Notarius CF, Levy RD, Tully A et al. Cardiac versus noncardiac limits to exercise after heart transplantation. Am Heart J 1998; 135: 339-48.

3. Wisløff U, Støylen A, Loennechen JP et al. Superior cardiovascular effect of aerobic interval training versus moderate continuous training in heart failure patients: a randomized study. Circulation 2007: 115: 3086-94.

4. Kobashigawa JA, Leaf DA, Lee $\mathrm{N}$ et al. A controlled trial of exercise rehabilitation after heart transplantation. N Engl J Med 1999; 340: $272-7$.

5. Tegtbur U, Busse MW, Jung K et al. Time course of physical reconditioning during exercise rehabilita- tion late after heart transplantation. J Heart Lung ransplant 2005: 24: $270-4$

6. Bernardi L, Radaelli A, Passino $C$ et al. Effects of physical training on cardiovascular control after heart transplantation. Int J Cardiol 2007: 118: $356-62$

7. Karapolat H, Eyigor S, Zoghi M et al. Effects of car diac rehabilitation program on exercise capacity and chronotropic variables in patients with orthotopic heart transplant. Clin Res Cardiol 2008: 97. 449-56.

8. Wu YT, Chien CL, Chou NK et al. Efficacy of a homebased exercise program for orthotopic heart transplant recipients. Cardiology 2008; 111: 87-93.

9. Rognmo O, Hetland E, Helgerud J et al. High intensity aerobic interval exercise is superior to moderate intensity exercise for increasing aerobic capacity in patients with coronary artery disease. Eur J Cardiovasc Prev Rehabil 2004: 11: 216-22.

10. Haykowsky M, Taylor D, Kim D et al. Exercise training improves aerobic capacity and skeletal muscle function in heart transplant recipients. Am J Transplant 2009: 9: 734-9.

11. Hermann TS, Dall CH, Christensen SB et al. Effect of high intensity exercise on peak oxygen uptake and endothelial function in long-term heart transplant recipients. Am J Transplant 2011; 11: $536-41$.
12. Nytrøen K, Rustad LA Aukrust P et al. Highintensity interval training improves peak oxygen uptake and muscular exercise capacity in heart transplant recipients. Am J Transplant 2012; 12 $3134-42$

13. Nytrøen K, Annette Rustad L, Erikstad I et al. Effect of high-intensity interval training on progression of cardiac allograft vasculopathy. J Heart Lung Transplant 2013; e-publisert 29.7.2013.

14. Nytrøen K, Myers J, Chan KN et al. Chronotropic responses to exercise in heart transplant recipients: 1-year follow-up. Am J Phys Med Rehabil 2011; 90: 579-88.

15. Nytrøen K, Gullestad L. Exercise after heart trans plantation - an overview. World J Transplant 2013 akseptert for publisering.

Mottatt 5.7. 2013, første revisjon innsendt 29.8. 2013, godkjent 15.9. 2013. Redaktør Hanne Støre Valeur.

Publisert først på nett.

\section{SILURVEIEN 2 - NYE KONTORER TIL LEIE NAER RADIUMHOSPITALET}

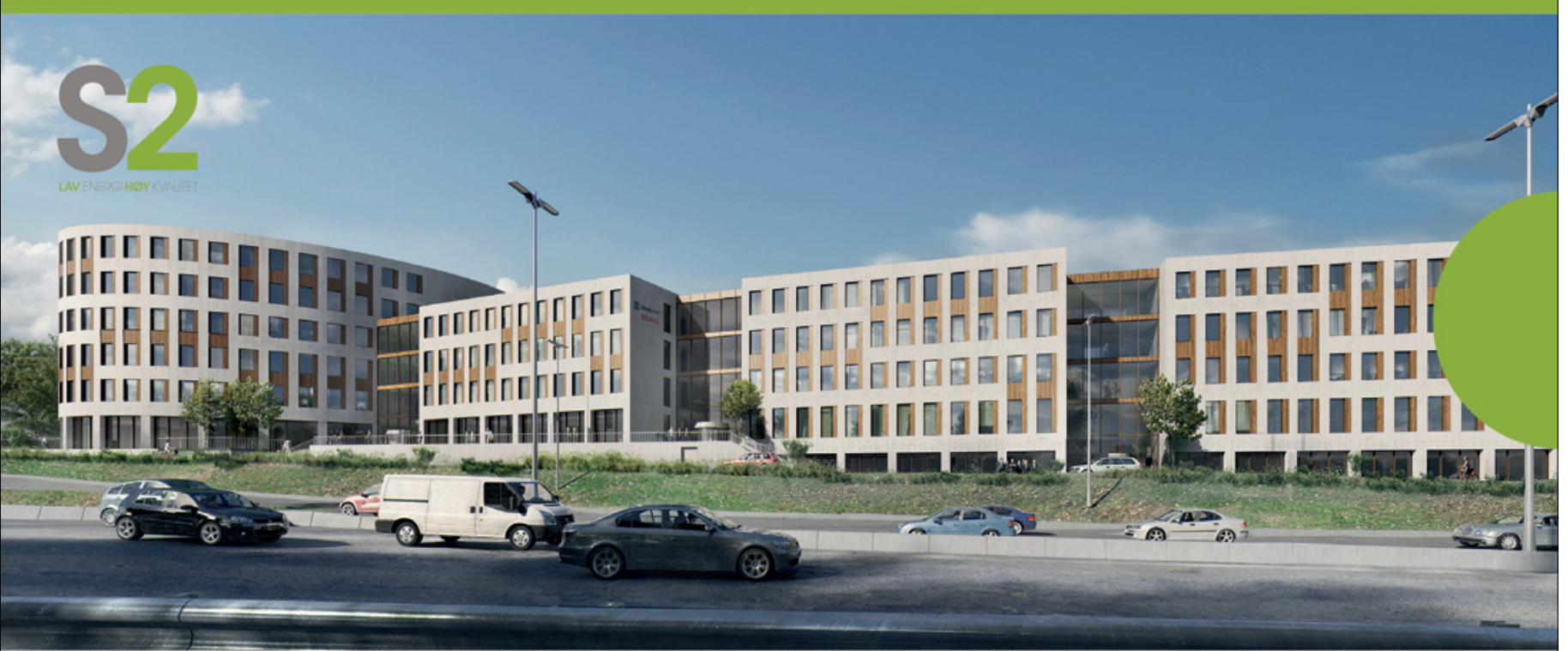

Ledig areal:

$14.000 \mathrm{kvm}$

Minimum utleieareal:

$750 \mathrm{kvm}$

Ledig fra:

Q4 2014
- Meget presentable kontorer + 3 m takhøyde

- Nybygg - Byggingen er i gang

- Profilert fasade mot Ring 3

- 270 p-plasser i underetasje med Elbil-pool

- Personalrestaurant og Wayne's Coffee

- God offentlig kommunikasjon (T-bane, trikk og buss)

- Energiklasse A

SELVAAG

\section{Kontakt}

Rune Arvesen

91535567

ra@akershuseiendom.no

wuw. silurveien2.no

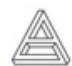

$\triangle K E R S H U S$

EIENDOM 